\title{
Video Pembelajaran untuk Peningkatan Kemampuan Bahasa Inggris Tingkat Sekolah Dasar
}

\author{
Devi Maharani Santika ${ }^{1 *}$, Mahatma Agung $^{2}$, Kadek Apriliani ${ }^{3}$ iD \\ ${ }^{1,2,3}$ Universitas Mahasaraswati Denpasar, Denpasar, Indonesia \\ *Corresponding author: Santika898@gmail.com
}

\begin{abstract}
Abstrak
Tantangan dalam melakukan proses belajar mengajar secara daring adalah memastikan materi pelajaran dapat tersampaikan dengan baik kepada peserta didik. Berdasarkan pengamatan yang dilakukan di SDN 11 Dauh Puri Denpasar, khususnya di kelas 3, materi pembelajaran belum tersampaikan dengan baik karena hanya mengandalkan media pembelajaran yang konvensional yaitu buku lembar kerja siswa (LKS) yang dimiliki siswa dan dikerjakan oleh siswa berdasarkan instruksi melalui pesan pada WhatsApp. Kegiatan ini berupaya untuk memberikan pilihan lain dalam menyampaikan materi Bahasa Inggris pada siswa-siswa sekolah dasar SDN 11 Dauh Puri Denpasar, sehingga materi pelajaran yang telah tersusun dapat tersampaikan dengan baik dan optimal. Metode pelaksanaan kegiatan ini observasi, questionnaire dan metode demonstrasi melalui video pembelajaran. Selain itu, latihan intensif diberikan untuk mengetahui sejauh mana pemahaman peserta didik terhadap materi yang diberikan. Hasil yang diperoleh adalah metode video pembelajaran yang di lakukan di sekolah dasar ini membantu peserta didik untuk lebih memahami materi yang disampaikan, karena mereka dapat melihat dan mendengarkan secara langsung bagaimana pengajar mengucapkan kata atau kalimat dalam Bahasa Inggris. Selain itu, video pembelajaran menjadi kegiatan yang terintegrasi untuk mempelajari keempat keterampilan berbahasa, yaitu, reading, writing dan listening.
\end{abstract}

Kata Kunci: Video Pembelajaran, Daring, Sekolah Dasar

\section{Abstract}

The challenge in conducting the online teaching and learning process is to ensure that the subject matter can be conveyed properly to students. Based on observations made at SDN 11 Dauh Puri Denpasar, especially in grade 3, learning materials have not been conveyed properly because they only rely on conventional learning media, namely student worksheets (LKS) owned by students and carried out by students based on instructions via messages on WhatsApp. This activity seeks to provide other options in delivering English material to elementary school students at SDN 11 Dauh Puri Denpasar, so that the subject matter that has been arranged can be delivered properly and optimally. The method of implementing this activity is observation, questionnaire and demonstration method through learning videos. In addition, intensive training is given to determine the extent of students' understanding of the material provided. The results obtained are that the video learning method carried out in elementary schools helps students to better understand the material presented, because they can see and listen directly to how the teacher pronounces words or sentences in English. In addition, learning videos are an integrated activity to learn the four language skills, namely, reading, writing and listening.

Keywords: Learning Video, Onlinel, Primary School

\section{PENDAHULUAN}

Dengan adanya situasi pandemic akibat Covid - 19 ini, sejak pertengahan tahun 2020 kegiatan belajar mengajar di seluruh tingkat pendidikan diadakan secara daring. Perubahan dari pembelajaran secara tatap muka di kelas menjadi pembelajaran secara daring dengan menggunakan aplikasi-aplikasi tertentu membuat para guru dan peserta didik harus beradaptasi dengan segera agar proses belajar mengajar (PBM) dapat terus berlangsung (Thaib, 2013). Tantangan yang dihadapi para guru dalam proses belajar mengajar secara daring ini salah satunya adalah memastikan materi dapat tersampaikan dengan baik dan

$\begin{array}{ll}\text { History: } & \\ \text { Received } & \text { : September 10, } 2021 \\ \text { Revised } & \text { : September 12, } 2021 \\ \text { Accepted } & \text { : November 03, } 2021 \\ \text { Published } & \text { : November } 25,2021\end{array}$


optimal. Khusus pelajaran Bahasa Inggris di tingkat sekolah dasar, materi-materi yang diberikan haruslah dapat menyentuh keempat skill berbahasa, yaitu menulis, mendengarkan, membaca dan berbicara (Keraf \& Gorys, 2004; Miswaty et al., 2020; Octavita \& Saraswati, 2017). Selain hal tersebut, pelatihan mengenai materi tersebut harus terus dilakukan agar peserta didik dapat memahami serta mengingat materi dengan baik. Bahasa Inggris merupakan Bahasa asing yang jarang dipakai dalam interaksi sehari-hari. Sehingga akan menjadi tidak mudah untuk mengajarkan nya secara daring (Febriyanti \& Sundari, 2020). Seperti yang dihadapi oleh para guru di SDN 11 Dauh Puri Denpasar, pembelajaran Bahasa Inggris di sekolah ini hanya dilakukan sekali seminggu, sehingga kegiatan mempraktekkan Bahasa Inggris secara intensif merupakan hal yang sulit untuk dilakukan. Padahal dalam masa anak sekolah dasar ini masih termasuk masa dini untuk mempelajari Bahasa, sehingga akan memiliki kecepatan dalam menguasai phonetic dan fonologi dari suatu Bahasa kedua (Amiruddin \& Jannah, 2021).

Pentingnya pengajaran Bahasa Inggris terutama yang ditanamkan dari sejak dini telah dibuktikan dalam beberapa kegiatan pengabdian masyarakat dalam beberapa tingkatan pendidikan maupun bidang pekerjaan yang membutuhkan pengetahuan ini (Risnawaty, 2021; Ruminda \& Kustanti, 2018). Menurut peneliti yang melakukan pengajaran bagi pemandu wisata di Desa Serangan, Bali ditemukan bahwa adanya perbedaan latar belakang pendidikan pemerolehan Bahasa inggris para pemandu wisata ini bervariasi (Putri et al., 2018). Pemberian kegiatan pembelajaran yang hanya berorientasi pada latihan tanpa terlebih dahulu memberikan materi secara terperinci kepada siswa juga terlihat dalam cara pengajaran di SDN Dauh Puri Denpasar. Serupa dengan temuan dalam kegiatan pengabdian pelatihan Bahasa Inggris terhadap guru-guru PAUD-TK-MI di Desa Abar Abir, yaitu fenomena guru yang hanya berorientasi dalam mengajarkan bentuk (form) daripada isi (content). Hal ini dianggap tidak efektif karena anak-anak usia dini tersebut tidak dapat melihat konteks penggunaannya dalam keseharian mereka (Masruroh et al., 2018).

Para guru juga dapat menjadi subjek pelatihan Bahasa Inggris karena mereka adalah contoh yang akan dilihat oleh para siswa saat dikelas (Putri \& Santika, 2020). Selama pembelajaran daring di SDN 11 Dauh Puri, Guru Bahasa Inggris tidak dapat sepenuhnya hadir dihadapan siswa, sehingga siswa tidak dapat mencontoh apa yang dilakukan guru, untuk dapat menguasai materi sesuai harapan, terutama dalam penguasaan speaking skill. Menurut penelitian untuk menguasai speaking skill, siswa hendaknya mengucapkan phonemes dengan tepat, menggunakan penekanan dan intonasi yang sesuai (Harmer. \& Jeremy., 2007). Karena itu kehadiran guru dihadapan siswa secara langsung untuk memberi contoh akan sangat berguna.

Sekolah SDN 11 Dauh Puri hanya memiliki 1 orang guru Bahasa Inggris yang mengajar ke-enam kelas yang ada di sekolah tersebut. Selain itu mata pelajaran Bahasa Inggris hanya dijadwalkan 1 kali dalam seminggu, sehingga dapat dipastikan proses praktek penggunaan Bahasa Inggris bagi para siswa tidak dapat dilakukan secara maksimal. Dimasa pandemi Covid - 19 ini, Sekolah ini juga menerapkan metode pembelajaran secara daring. Media yang digunakan adalah WhatsApp karena melihat kondisi ekonomi sebagian besar orang tua siswa SDN 11 Dauh Puri yang sebagian besar ada pada kelas menengah ke bawah. Jika menggunakan aplikasi daring lainnya yang membutuhkan banyak kuota internet dan juga membutuhkan gadget khusus, orang tua siswa mengalami kesulitan untuk memenuhi hal-hal tersebut. Terbatas nya aplikasi yang digunakan untuk PBM di sekolah ini membuat penyampaian materi menjadi tidak maksimal, terutama dalam Bahasa Inggris yang diberikan sekali seminggu (Gulo et al., 2021; Soeharyono et al., 2022). Guru terpaksa hanya memberikan materi dengan model printed sheet dan diikuti latihan dari buku LKS yang sudah dimiliki siswa. Pada kegiatan pengabdiannya, sarana dan prasana teknologi untuk kegiatan di sekolah telah menjadi masalah yang kini membutuhkan perhatian serius, terutama 
karena sangat dibutuhkan dalam masa pembelajaran jarak jauh ini (Kurniawan \& Purnomo, 2020). Melihat fenomena diatas, maka kegiatan pengabdian ini diadakan untuk membantu guru memberikan materi Bahasa Inggris dengan lebih maksimal kepada peserta didik agar dapat meningkatkan pemahaman peserta didik terhadap pelajaran Bahasa Inggris dengan lebih baik.

\section{METODE}

Kegiatan pengabdian ini dilakukan di Sekolah Dasar Negeri 11 Dauh Puri Denpasar. Sasaran kegiatan adalah para siswa di kelas 3, karena kelas ini dianggap sudah mampu mengikuti pembelajaran dengan cara mandiri. Selain itu pengetahuan Bahasa Inggris yang diperoleh di kelas ini akan menjadi dasar untuk materi yang lebih kompleks di kelas lanjutannya. Materi yang diberikan pada kelas ini saat kegiatan pengabdian dilaksanakan adalah: Hobby, Pets, Months, dan Ordinal Number (Date). Metode observasi dilakukan terlebih dahulu untuk melihat keadaan pembelajaran khususnya Bahasa Inggris di sekolah ini. Tim mengamati cara pembelajaran Bahasa Inggris di kelas 3 yang dilakukan secara daring dan berdiskusi dengan guru Bahasa Inggris mengenai kesulitan yang dihadapi dalam menyampaikan materi kepada siswa secara daring serta mendapatkan gambaran umum tentang ketercapaian hasil belajar para siswa dalam mata pelajaran ini. Tim juga mendiskusikan materi yang akan disampaikan di kelas 3, sehingga tim dapat menyusun materi ajarnya. Selanjutnya, dari hasil observasi dan diskusi tersebut, tim menentukan yang sesuai dengan teknologi yang dapat diakses dan dipahami oleh wali murid maupun para siswa. Metode pengajaran yang menurut tim tepat untuk dilakukan adalah secara demonstrasi. Metode demonstrasi sangat efektif untuk menyampaikan penekanan praktek pengajaran secara langsung (Ubaedillah et al., 2020). Namun karena situasi pembelajaran di SDN 11 Dauh Puri yang masih bersifat daring, maka demonstrasi dilakukan melalui bentuk video imaginative. Tim pelaksana kegiatan ini terdiri dari 3 dosen Bahasa Inggris. Kegiatan dilaksanakan dalam waktu 6 bulan dimulai dari bulan Januari- Juni 2021. Setiap minggunya pengajaran dilakukan 1x seminggu dengan durasi pertemuan selama 1 jam. Adapun tahap pelaksanaan kegiatan ini disajikan pada Tabel 1.

Tabel 1. Tahapan kegiatan pengabdian di SDN 11 Dauh Puri

\begin{tabular}{|c|c|c|c|}
\hline Kegiatan & Waktu & & \\
\hline $\begin{array}{l}\text { 1. Melakukan observasi ke Sekolah SDN } \\
11 \text { Dauh Puri }\end{array}$ & Awal Januari 2021 & & \\
\hline 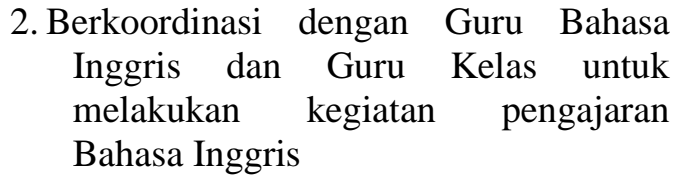 & Minggu Kedua Januari 2021 & & \\
\hline $\begin{array}{l}\text { 3. Menyiapkan Materi berupa video } \\
\text { pembelajaran }\end{array}$ & $\begin{array}{l}\text { Minggu ketiga Januari } \\
\text { Februari } 2021\end{array}$ & - Minggu & pertama \\
\hline 4. Mengajar topik 1 & Februari 2021 & & \\
\hline 5. Mengajar topik 2 & Maret 2021 & & \\
\hline 6. Mengajar topik 3 & April 2021 & & \\
\hline 7. Mengajar topik 4 & Mei 2021 & & \\
\hline 8. Penyebaran Kuesioner & Juni 2021 & & \\
\hline
\end{tabular}

Metode kuesioner serta pemberian exercise juga dilakukan untuk dapat melihat pendapat para wali murid kelas 3 mengenai pembelajaran Bahasa Inggris yang dilakukan oleh guru dan untuk menilai keberhasilan kegiatan pengajaran yang dilakukan oleh Tim. Alasan membagikan kuesioner kepada wali murid, karena selama ini merekalah yang 
menemani peserta didik untuk belajar. Untuk memotivasi siswa melakukan latihan, maka soal-soal latihan dibuat dengan gambar yang colorful pada google form dan worksheet. Soalsoal latihan diberikan pada saat yang bersamaan dengan penyampaian video pembelajaran tersebut. Hasil ketercapaian kegiatan ini akan disampaikan secara deskripsi dengan menggunakan diagram dan tabel.

\section{HASIL DAN PEMBAHASAN}

\section{Hasil}

Bahasa Inggris yang digunakan dalam berkomunikasi lisan maupun tulisan sangat bergantung pada penguasaan kosakata yang baik (Sari \& Sembiring, 2021). Namun dengan adanya mindset bahwa Bahasa Inggris itu sulit, terutama pada anak-anak, maka apapun yang akan disampaikan terkait Bahasa Inggris akan susah untuk diterima oleh mereka (Ruhaena, 2008; Warman et al., 2020). Hal tersebut juga menjadi temuan dalam kegiatan pengabdian di sekolah ini. Pelajaran Bahasa inggris termasuk pelajaran yang dianggap sulit dan juga karena pertemuan di kelas hanya dilakukan 1 kali seminggu, hal tersebut tidak memungkinkan para peserta didik untuk berlatih secara intensive dan rutin. Temuan lainnya adalah pemberian materi pelajaran Bahasa Inggris yang tidak maksimal kepada peserta didik. Kegiatan pengabdian ini berusaha untuk memberikan pandangan lain terhadap pembelajaran Bahasa Inggris khususnya untuk Guru pengajar Bahasa Inggris maupun siswa-siswa kelas 3 sekolah dasar di SDN 11 Dauh Puri. Dengan berbagi pengetahuan terutama dalam hal penyampaian materi kepada Guru Bahasa Inggris di sekolah ini, diharapkan adanya variasi penyampaian materi kepada peserta didik. Selain itu berbagi pengetahuan akan membantu memberikan semangat untuk belajar Bahasa Inggris (Santoso et al., 2021).

\section{Pemberian Materi Bahasa Inggris dengan Video Pembelajaran}

Guru harus memiliki keyakinan untuk memanfaatkan dan menciptakan media pembelajaran yang selaras dengan situasi para siswa dan materi yang hendak disampaikan (Wijirahayu et al., 2019). Melihat temuan di lapangan bahwa materi tidak dapat disampaikan dengan maksimal dengan hanya menggunakan materi tertulis, tim kegiatan ini memutuskan untuk membuat video pembelajaran Bahasa Inggris yang dibagikan melalui aplikasi WhatsApp (Mustofa et al., 2021; Nurdin et al., 2019). Ini membuktikan bahwa teknologi sebenarnya dapat mempermudah pengajaran Bahasa Inggris (Muttaqien, 2017). Selain membantu memahami materi, cara belajar dengan menggunakan teknologi menjadi tantangan dan hal baru bagi peserta didik. Namun karena melihat keterbatasan peserta didik dalam mengakses teknologi untuk pembelajaran, seperti yang terjadi di sekolah ini, maka guru harus menentukan media yang sesuai dengan keadaan peserta dididk. Video pembelajaran ini dapat diunduh melalui smartphone, dimana teknologi ini yang paling banyak dimiliki dan dapat digunakan oleh wali murid (Hendrayani et al., 2018). Adapun materi yang diberikan selama kegiatan pengabdian disajikan pada Tabel 2.

Tabel 2. Materi bahasa Inggris kelas 3

\begin{tabular}{|c|c|c|}
\hline No & Topik & Materi yang diajarkan \\
\hline 1. & Family & $\begin{array}{l}\text { a. kata - kata tentang keluarga, } \\
\text { b. Possessive pronoun: his, her, mine,etc } \\
\text { c. Percakapan tentang menceritakan keluarga } \\
\text { d. Menggambarkan silsilah keluarga }\end{array}$ \\
\hline 2. & $\begin{array}{l}\text { Fruit and } \\
\text { vegetables }\end{array}$ & $\begin{array}{l}\text { a. kata-kata tentang buah-buahan yang dikonsumsi sehari-hari, maupun } \\
\text { buah-buahan musiman } \\
\text { b. Ekspresi suka dan tidak suka (like, dislike) }\end{array}$ \\
\hline
\end{tabular}




\begin{tabular}{lll}
\hline No & \multicolumn{1}{c}{ Topik } & \multicolumn{1}{c}{ Materi yang diajarkan } \\
\hline & & c. Text tentang Buah kegemaran \\
& d. Yes/no question with do/does + like \\
3. My Body & a. Kata-kata tentang bagian tubuh \\
& b. Penggunaan have dan has \\
& c. Kegunaan bagian-bagian tubuh \\
& d. Mendeskripsikan diri sendiri \\
4. My House & a. Kata-kata tentang perlatan dan bagian rumah \\
& b. Kegunaan ruangan-ruangan di rumah \\
& c. Penggunan artikel this, these, that dan those. \\
& d. Teks menceritakan keadaan rumah masing-masing \\
\hline
\end{tabular}

Guru bahasa Inggris membantu memberikan 4 topik yang disebutkan pada kolom 1. Kemudian tim mengembangkan topik-topik tersebut menjadi beberapa materi yang memungkin siswa melatih ke-empat kemampuan berbahasa, yaitu: writing, reading, listening dan speaking. Materi - materi tersebut dituangkan dalam bentuk video pembelajaran dan di share melalui WhatsApp. Pada umumnya dalam setiap video yang disiapkan pada kegiatan ini, perkenalan vocabulary untuk setiap topik selalu diberikan (Fuada \& Marhamah, 2021). Vocabulary digunakan dalam keempat keterampilan bahasa seperti : menulis, membaca, berbicara dan mendengarkan. Keempat keterampilan tersebut tebagi pada istilah receptive dan productive skills (Harmer. \& Jeremy., 2007; Wijirahayu \& Septiani, 2017). Receptive skill adalah keterampilan untuk membaca dan mendengarkan yang diperoleh dari sebuah wacana (discourse), sedangkan Productive Skills adalah ketrampilan untuk menguasai speaking dan writing yang sebenarnya siswa harus memproduksinya sendiri. Sangatlah mustahil untuk tidak saling menghubungkan keempat keterampilan berbahasa tersebut dalam sebuah pembelajaran Bahasa Inggris. Video yang dibuat dalam pengajaran di kegiatan ini memiliki kegunaan untuk mendapatkan keterampilan diatas secara bersamaan, dengan cara: melihat tulisan dari kata-kata yang dicantumkan dalam video (reading); mendengarkan suara pengajar yang membaca kata yang ditampilkan tersebut (listening); mengajak siswa mengucapkan kembali kata-kata yang tercantum di video (speaking); menuliskan kembali kata-kata yang diperoleh dalam bentuk latihan soal-soal yang dan juga membuat kalimat sederhana dengan kata-kata yang diberikan (writing).
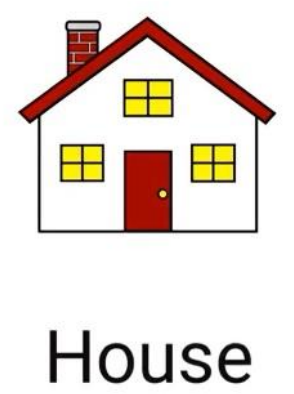

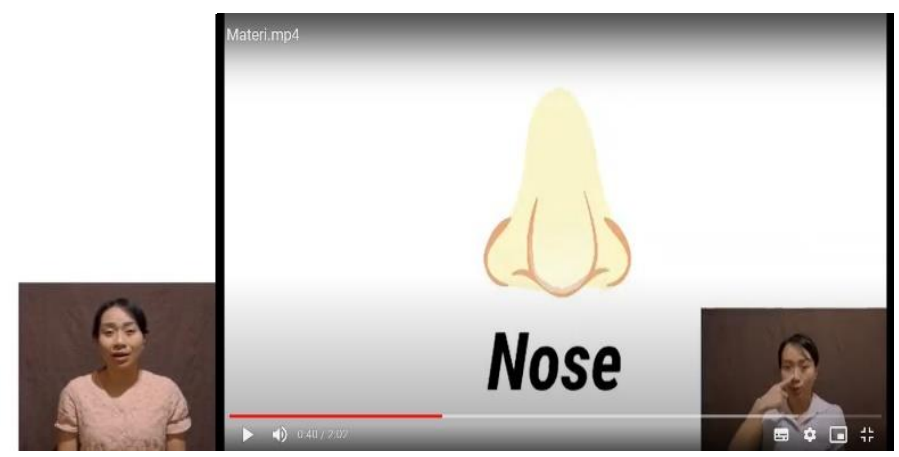

Gambar 1. Contoh video pembelajaran part of body dan my house

Seperti pada Gambar 1, tim membuat video yang berisi materi tentang part of body. Ada 10 part of body yang ditampilkan dalam video disertai dengan pengucapan yang benar oleh pengajar. Pengucapan menjadi penting dalam pelajaran Bahasa Inggris, karena kata-kata dalam Bahasa Inggris berbeda dengan kata-kata dalam Bahasa Indonesia. Bunyi yang muncul dari alat ucap manusia termasuk cara berkomunikasi yang digunakan masyarakat (Nurcholis \& Hidayatullah, 2019). Oleh sebab itu, pengajar mengucapkan setiap kata dengan jelas sesuai 
gambar dan dilakukan sebanyak 2x sebagai bentuk metode repetitive atau pengulangan. Sebenarnya yang disebut belajar adalah mengulang materi yang telah diperoleh (Wijoyo, 2020). Jadi dengan metode pengulangan ucapan dalam video pembelajaran yang diberikan oleh tim diharapkan siswa dapat mempelajari kata-kata tersebut dengan baik. Setelah pemberian materi, siswa diajak untuk mengisi google form dan worksheet yang merupakan bentuk latihan dari materi yang diberikan. Bentuk Latihan soal-soal diuraikan sebagai berikut: Teks sederhana sesuai topik bahasan disertai dengan soal-soal untuk pemahaman teks; Kalimat-kalimat sederhana untuk dilengkapi yang memuat kosakata yang diajarkan; Menjodohkan kata-kata dengan gambar; Pilihan ganda, untuk memilih jawaban yang tepat, baik utk soal terjemahan atau melengkapi kalimat; Menentukan kalimat yang benar atau salah

\section{Kesesuaian metode pengajaran terhadap situasi pembelajaran siswa kelas 3 secara daring}

Seperti yang telah disampaikan diatas bahwa kegiatan ini membantu guru Bahasa Inggris di kelas 3 SDN Dauh Puri Denpasar untuk menyampaikan materi Bahasa Inggris kepada para siswa. Selama PBM jarak jauh diterapkan dari tahun 2020, media teknologi yang dipilih oleh Guru untuk mengajar adalah via WhatsApp. Materi yang diberikan berdasarkan LKS serta beberapa sumber yang dituangkan oleh guru dalam bentuk printed sheet dan dibagikan melalui WhatsApp Group. Dengan keadaan ini, menurut observasi tim, siswa dituntun untuk belajar dan memahami sendiri materi yang diberikan. Hal ini tergambarkan dalam hasil jawaban orang tua murid atas pertanyaan di kuesioner: 'Bagaimana tingkat pemahaman siswa untuk materi yang diberikan Guru?'. Gambar 2 menunjukkan hasil pertanyaan tersebut.

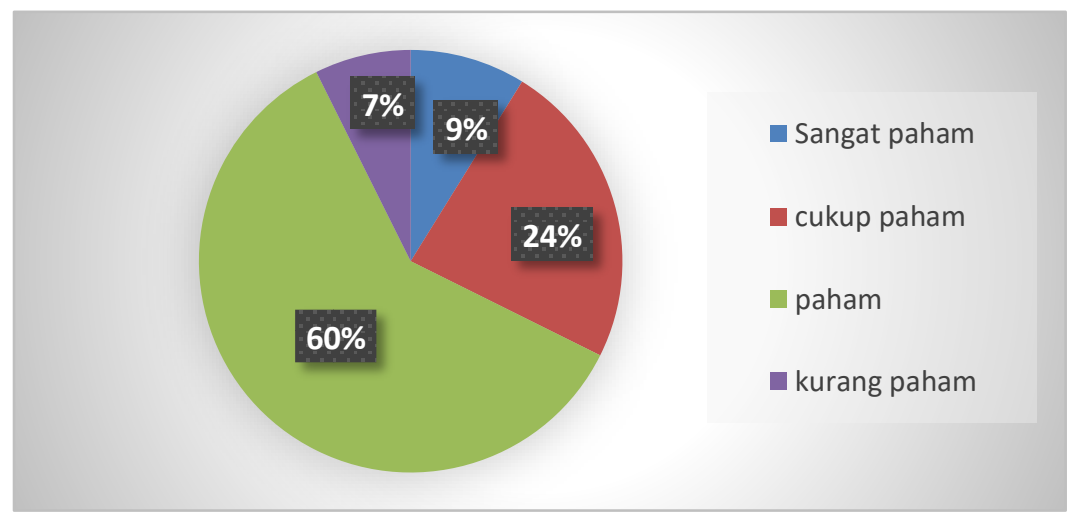

Gambar 2. Pertanyaan kuesioner No 1

Untuk kesulitan yang ditemukan saat memahami materi dan juga saat mengerjakan soal - soal sesuai materi yang diberikan Guru, orang tua siswa mengarahkan anak-anak untuk mencarinya melalui internet (terutama menggunakan google search atau google translate). Pernyataan ini diperoleh dari kuesioner yang dibagikan dengan pertanyaan: 'Bagaimana cara memahami materi yang diberikan Guru?' Gambar 3 menunjukkan presentasi jawaban para orang tua murid: 


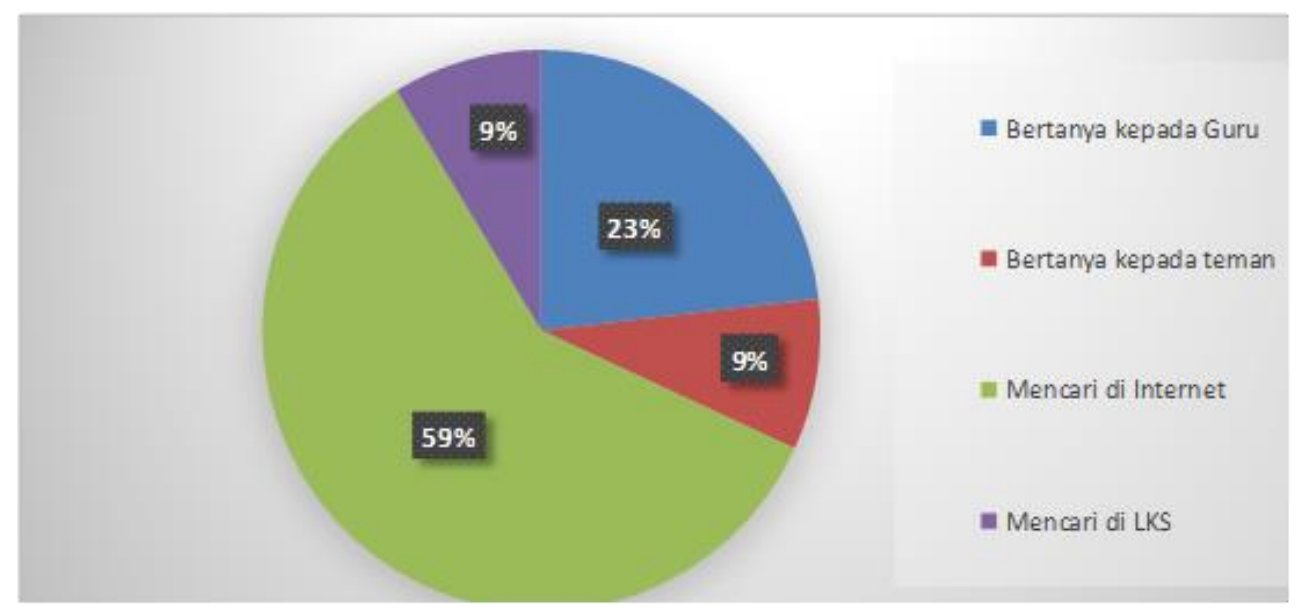

Gambar 3. Pertanyaan kuesioner No 2

Seperti yang disampaikan diatas, keadaan ekonomi para wali murid di SDN 11 Dauh Puri berada pada tingkat menengah ke bawah, sehingga untuk melakukan pembelajaran daring selain menggunakan Whatsapp akan menyulitkan para orang tua. Beberapa alasannya antara lain: terbatasnya anggaran untuk membeli kuota, dan ketersediaan gadget untuk terbatas dalam 1 rumah para siswa tersebut. Pada gambar. 2, menunjukkan situasi siswa saat sedang mengerjakan soal-soal dari materi yang telah diberikan. Bagi yang berada pada keluarga kelas menengah, mereka menggunakan laptop untuk mengerjakan sola. Sedangkan yang lainnya kebanyakan menggunakan smartphone orang tuanya untuk mengerjakan soal. Mereka dengan mudah menjawab soal-soal tersebut karena telah merasa paham atas materi yang diberikan. Hal ini pun sesuai dengan kuesioner yang diberikan kepada orang tua murid yang mendampingi para siswa belajar dengan pertanyaan: Bagaimana tingkat pemahaman siswa terhadap materi yang diberikan melalui video pembelajaran? Gambar 4 menunjukkan hasil atas pertanyaan diatas.

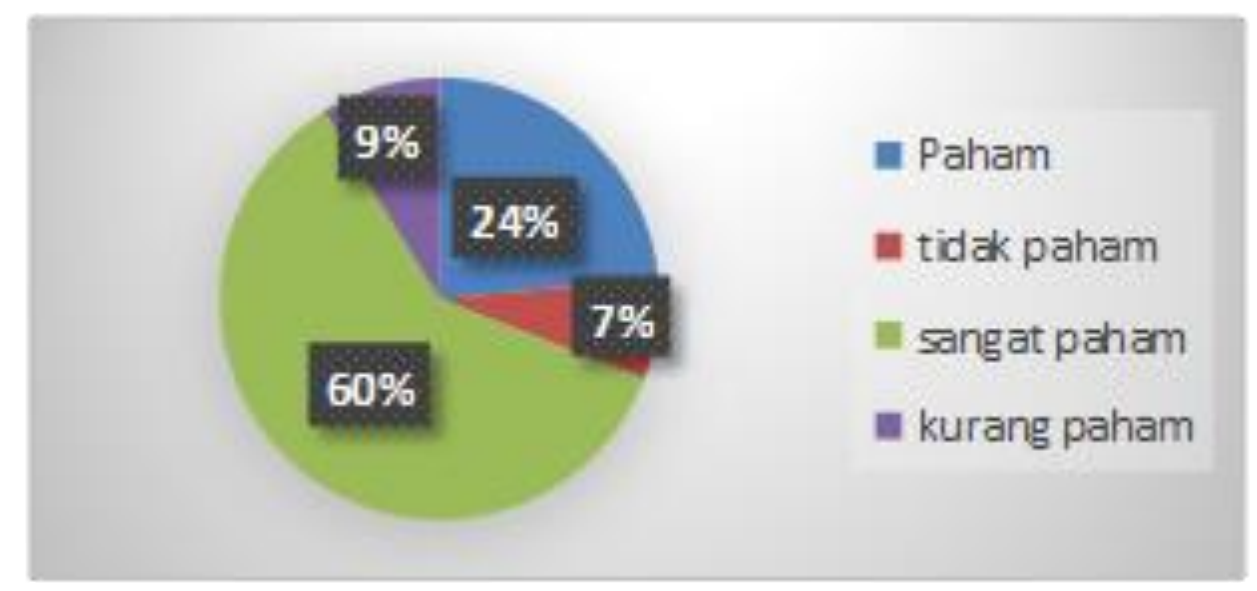

Gambar 4. Pertanyaan kuesioner No 3

Selanjutnya adalah efektifitas pemberian video pembelajaran ditunjukkan dalam respon para orang tua dalam pertanyaan di kuesioner: Menurut anda, seberapa efektif nya pemberian materi menggunakan video pembelajaran? Sebagian besar respon menunjukkan orang tua berpendapat video pembelajaran sangat efektif dalam menyampaikan materi pelajaran bahasa Inggris. Hasil respon dari orang tua siswa ditunjukkan pada Gambar 5. 


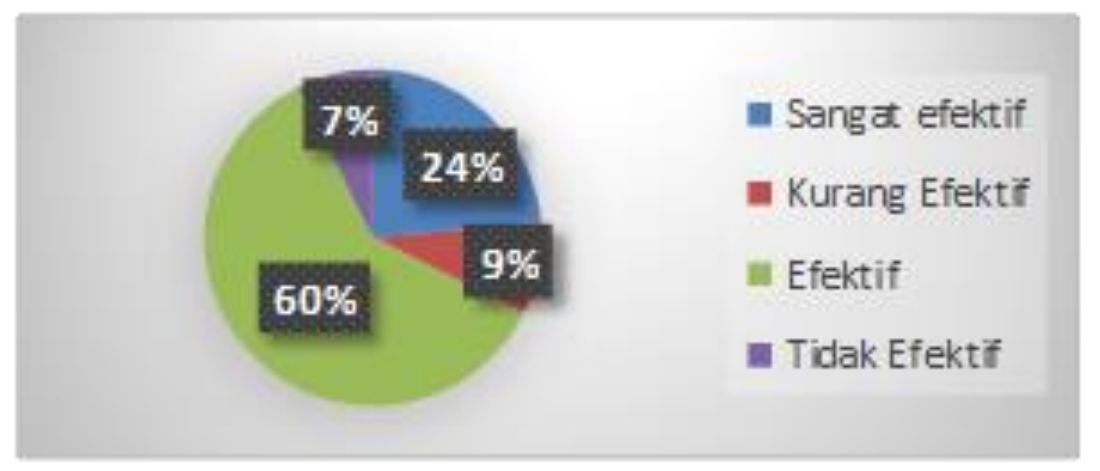

Gambar 5. Pertanyaan kuesioner No 4

\section{Penilaian Siswa}

Selain melalui kuesioner yang diberikan kepada orang tua siswa, tolak ukur untuk pemahaman siswa dilakukan melalui nilai-nilai yang diperoleh siswa saat mengerjakan soalsoal dari materi yang diberikan. Ada beberapa fungsi penilaian dalam pendidikan, salah satu nya adalah fungsi formatif (Rati \& Montessori, 2019). Fungsi penilaian ini untuk mengetahui tingkat keberhasilan suatu kegiatan pengajaran terhadap peserta didik. Maka penilaian melalui hasil latihan yang dikerjakan para siswa dapat dikategorikan sebagai penilaian formatif. Hasil latihan soal-soal yang diberikan pada siswa digambarkan pada Gambar 6.

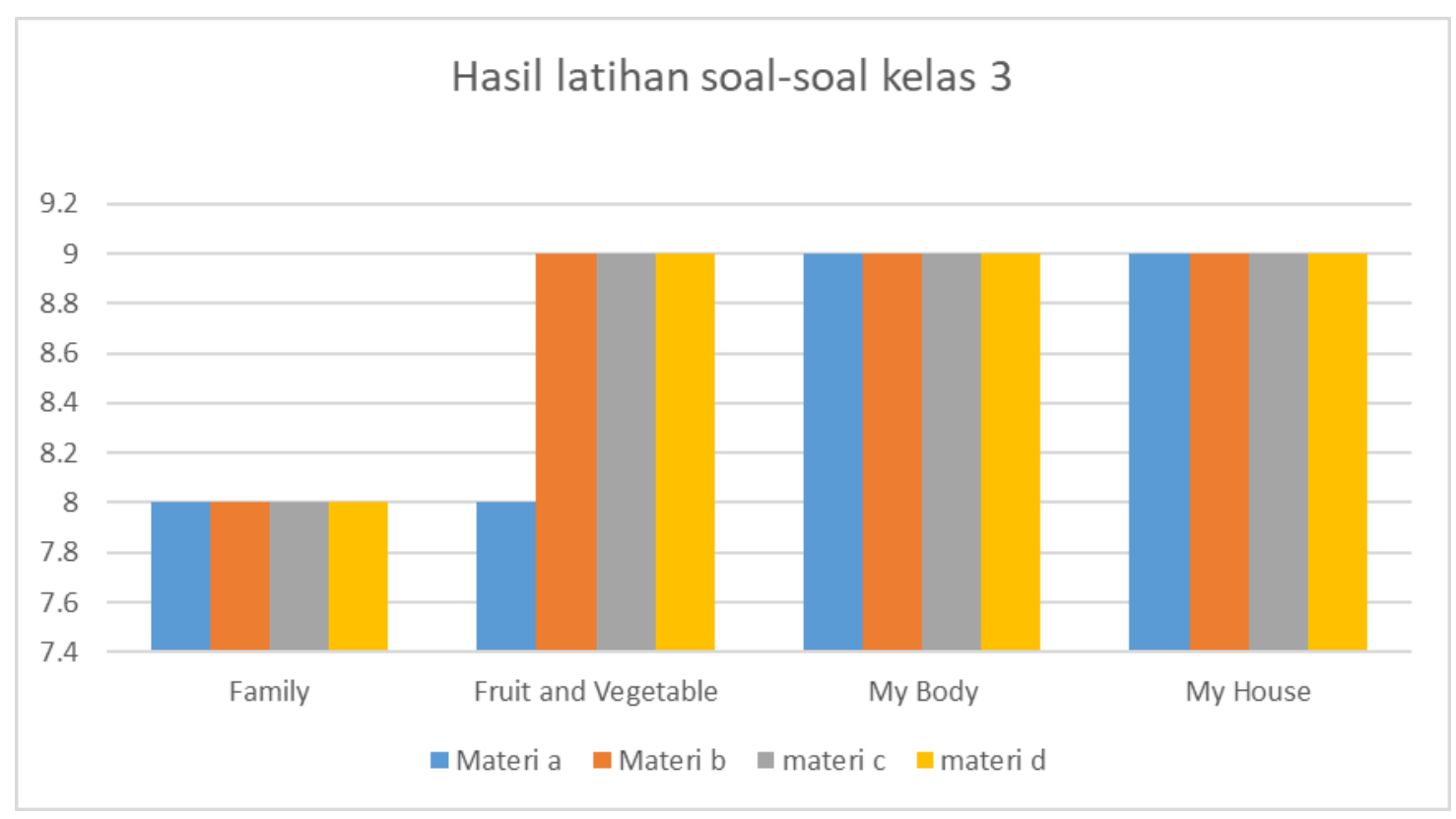

Gambar 6. Hasil Latihan Soal-Soal

Sesuai dengan table 1 diatas, soal-soal diberikan menurut materi yang sesuai dengan topik bahasan yang disampaikan oleh Guru Bahasa Inggris kelas 3 di SDN 11 Dauh Puri. Kemudian materi yang disampaikan dikembangkan kembali oleh tim, masing-masing menjadi 4 materi sesuai topik utama. Exercises yang dibuat untuk mengambil penilaian pemahaman para siswa disusun berdasarkan ke-empat hal tersebut pada setiap topik. Para siswa rata-rata mendapatkan nilai terendah 8 dari dan tertinggi 9. Hal ini menunjukkan bahwa siswa memahami materi dan materi menggunakan metode video pembelajaran tersampaikan dengan baik. 


\section{SIMPULAN DAN SARAN}

Materi Bahasa Inggris yang disampaikan melalui video pembelajaran pada kegiatan pengabdian ini merupakan metode pembelajaran yang terintegrasi dalam mencapai keterampilan berbahasa, yaitu reading, writing, speaking dan listening. Metode ini dapat menampilkan metode demonstrasi secara daring kepada peserta didik kelas 3 di sekolah SDN 11 Dauh Puri dalam pengajaran Bahasa Inggris. Kegiatan ini dapat dikatakan berhasil dilihat dari dua tolak ukur yang digunakan yaitu nilai yang diperoleh siswa melalui soal latihan di setiap akhir penyampaian masing-masing materi serta respond dari kuesioner yang dibagikan kepada orang tua. Tujuan tim untuk membantu guru Bahasa Inggris di Sekolah SDN 11 Dauh Puri dengan memberikan pilihan lain dalam penyampaian materi juga telah terlaksana. Video pembelajaran dapat dijadikan sarana lain untuk menyampaikan materi, selain materi tertulis, selama proses belajar mengajar secara daring. Dengan video tersebut, para siswa dapat mengulang kembali materi yang disampaikan sesuai kebutuhan mereka kapanpun mereka kehendaki. Hal ini secara tidak langsung akan membantu siswa meningkatkan pemahaman mereka tentang materi tersebut.

\section{UCAPAN TERIMAKASIH}

Tim mengucapkan terima kasih kepada Kepala Sekolah SDN 11 Dauh Puri, Guru Bahasa Inggris, serta Guru kelas 3 di SDN 11 Dauh Puri Denpasar karena telah sangat kooperatif dan membantu dalam segala aspek yang dibutuhkan saat tim melakukan pengabdian di Sekolah ini. Semoga kegiatan yang dilaksanakan dapat memberi manfaat positif untuk semua pihak.

\section{DAFTAR RUJUKAN}

Amiruddin, M., \& Jannah, U. R. (2021). Pelatihan Bahasa Inggris Bagi Anak Usia Dini di Daerah Terpencil Kecamatan Pademawu Pamekasan. Bima Abdi: Jurnal Pengabdian Masyarakat, 1(1), 18-22. https://doi.org/10.53299/bajpm.v1i1.34.

Febriyanti, R. H., \& Sundari, H. (2020). Penerapan Penggunaan Platform Dalam Pengajaran Bahasa Inggris Berbasis Daring. RANGKIANG: Jurnal Pengabdian Pada Masyarakat, 2(1), 17-27. https://doi.org/10.22202/rangkiang.2020.v2i1.4148.

Fuada, S., \& Marhamah, M. (2021). Read Aloud Video Sebagai Media Pembelajaran Daring pada Masa Pandemi Covid-19 di TK Aisyiyah Sidoharjo-Wonogiri. International Journal of Community Service Learning, 5(2). https://doi.org/10.23887/ijcsl.v5i2.33577.

Gulo, Y. T. M., Nasution, A. K., Batubara, B. M., \& Waruwu, S. (2021). Koncokelas: Aplikasi Video Pembelajaran Berbasis Animasi sebagai Usaha Pemberdayaan Anak Putus Sekolah melalui Rumah Belajar. Pelita Masyarakat, 2(2), 83-94. https://doi.org/10.31289/pelitamasyarakat.v2i2.4419.

Harmer., \& Jeremy. (2007). The Practice of English Language Teaching. Cambridge: Pearson Longman.

Hendrayani, Y., Jalinus, N., Delianti, V. I., \& Mursyida, L. (2018). Analisis Kebutuhan Pengembangan Media Pembelajaran Berbasis Video Tutorial. Jurnal Teknologi Informasi Dan Pendidikan, 11(2), 85-88. https://doi.org/10.24036/tip.v11i2.147.

Keraf, \& Gorys. (2004). Komposisi: Sebuah Pengantar Kemahiran Bahasa. Semarang: Bina Putra.

Kurniawan, B., \& Purnomo, A. (2020). Penggunaan Aplikasi Google Classroom Sebagai Upaya Peningkatan Pembelajaran Online Bagi Guru Matapelajaran IPS. International Journal of Community Service Learning, 4(1), 1-9. 
https://doi.org/10.23887/ijcsl.v4i1.22236.

Masruroh, L., Ainiyah, M., \& Hidayah, B. (2018). Pelatihan pengajaran bahasa Inggris usia dini bagi guru-guru bahasa Inggris di PAUD-TK-MI. JPP IPTEK (Jurnal Pengabdian Dan Penerapan IPTEK), 2(1), 33-36. https://doi.org/10.31284/j.jppiptek.2018.v2i1.247.

Miswaty, T. C., Syamsurrijal, S., Hadi, M. Z. P., \& Ulfa, B. A. (2020). Pelatihan Bahasa Inggris dan Pembukuan Keuangan bagi Masyarakat Desa Langko. Jurnal Pengabdian Undikma, 1(2), 166-171. https://doi.org/10.33394/jpu.v1i2.3082.

Mustofa, M. I., Amaliah, K., \& Kuspiyah, H. R. (2021). Pelatihan Pembuatan Video Mata Pelajaran Bahasa Inggris Materi Pokok Prosedur Teks Pada Siswa SMP. JMM (Jurnal Masyarakat Mandiri), 5(4), 1224-1233. http://journal.ummat.ac.id/index.php/jmm/article/view/5024.

Muttaqien, F. (2017). Penggunaan media audio-visual dan aktivitas belajar dalam meningkatkan hasil belajar vocabulary siswa pada mata pelajaran bahasa inggris kelas $\mathrm{x}$ (Quasy experiment: SMAN 8 Garut). Jurnal Wawasan Ilmiah, 8(1). https://jurnal.amikgarut.ac.id/index.php/jwi/article/view/27.

Nurcholis, A., \& Hidayatullah, S. I. (2019). Tantangan Bahasa Arab Sebagai Alat Komunikasi Di Era Revolusi Industri 4.0 Pada Pascasarjana IAIN Tulungagung. Arabiyatuna: Jurnal Bahasa Arab, 3(2), 283-298. https://scholar.archive.org/work/f5vepa27wvdvdoapqcu7rvaqu4/access/wayback/http: //journal.iaincurup.ac.id/index.php/ARABIYATUNA/article/download/999/pdf.

Nurdin, E., Ma'aruf, A., Amir, Z., Risnawati, R., Noviarni, N., \& Azmi, M. P. (2019). Pemanfaatan video pembelajaran berbasis Geogebra untuk meningkatkan kemampuan pemahaman konsep matematis siswa SMK. Jurnal Riset Pendidikan Matematika, 6(1), 87-98. https://doi.org/10.21831/jrpm.v6i1.18421.

Octavita, R. A. I., \& Saraswati, R. (2017). Integrasi Pendidikan Berkarakter Dalam Pembelajaran Bahasa Inggris. Jurnal Terapan Abdimas, 2, 33-40. https://doi.org/10.25273/jta.v2i0.974.

Putri, I. G. A. V. W., Candra, K. D. P., \& Santika, I. D. A. D. M. (2018). Pelatihan bahasa Inggris komunikatif untuk kelompok kerja "Serangan Transport" di desa adat Serangan. JPPM (Jurnal Pengabdian Dan Pemberdayaan Masyarakat), 2(1), 111119. https://doi.org/10.30595/jppm.v2i1.1780.

Putri, I. G. A. V. W., \& Santika, I. D. A. D. M. (2020). Training English for Educator at SMP Angkasa, Tuban-Kuta, Bali. International Journal of Community Service Learning, 4(4). https://doi.org/10.23887/ijcsl.v4i4.28883.

Rati, D., \& Montessori, M. (2019). Pelaksaan Penilaian Formatif Dalam Pembelajaran Ppkn Di Smp N 2 Lengayang. Journal of Civic Education, 2(1), 106-115. http://jce.ppj.unp.ac.id/index.php/jce/article/view/106.

Risnawaty, R. (2021). Pelatihan Short Conversation Dalam Bahasa Inggris pada Masyarakat Kerjasama Umn Al-Washliyah Dengan Kelurahan Desa Tualang Kecamatan Perbaungan. Prosiding Seminar Nasional Hasil Pengabdian, 474-480. https://www.eprosiding.umnaw.ac.id/index.php/pengabdian/article/view/783/761.

Ruhaena, L. (2008). Pengaruh metode pembelajaran jolly phonics terhadap kemampuan bacatulis permulaan Bahasa Indonesia dan Bahasa Inggris pada anak prasekola. Jurnal Penelitian Humaniora, 9(2), 190-204. http://jolly2.s3.amazonaws.com/Research/6. Lisnawati Ruhaena.pdf.

Ruminda, R., \& Kustanti, D. (2018). Pelatihan Speed Reading bagi Guru-Guru SD Mata Pelajaran Bahasa Inggris Se-Kecamatan Tarogong Kabupaten Garut. Al-Khidmat, 1(2), 67-76. http://journal.uinsgd.ac.id/index.php/al-khidmat/article/view/3337.

Santoso, A. B., Husain, B. A., Supiandi, G., Sudarso, A. P., \& Akbar, I. R. (2021). 
Knowledge Sharing Melalui Motivasi Belajar Dan Pelatihan Bahasa Inggris Pada Yayasan Domyadhu Pamulang. Dharma Laksana, 3(2), 106-109. https://doi.org/10.32493/j.pdl.v3i2.8796.

Sari, A. S. P., \& Sembiring, N. (2021). Pelatihan Penguasaan Kosakata Bahasa Inggris Dengan Menerapkan Model Pembelajaran Make A Match Bagi Siswa Sd Di Kelurahan Tunggurono Kota Binjai. Jurnal Pendidikan Dan Pengabdian Masyarakat, 4(3). https://jurnalfkip.unram.ac.id/index.php/JPPM/article/view/2863/1891.

Soeharyono, J. N. I., Budiman, M. A., \& Damayani, A. (2022). Efektivitas Pembelajaran Daring Menggunakan Media Online Selama Pandemi Covid-19 Pada Mata Pelajaran Bahasa Inggris Kelas Iv Sd Negeri Pengkol Jepara. Praniti: Jurnal Pendidikan, Bahasa, Dan Sastra, 2(1), 43-53. http://jurnal.unw.ac.id/index.php/praniti/article/view/1477.

Thaib, E. N. (2013). Hubungan Antara prestasi belajar dengan kecerdasan emosional. Jurnal Ilmiah Didaktika: Media Ilmiah Pendidikan Dan Pengajaran, 13(2). https://doi.org/10.22373/jid.v13i2.485.

Ubaedillah, U., Pratiwi, D. I., Mukson, M., Masrikhiyah, R., \& Nurpratiwiningsih, L. (2020). Pelatihan Wawancara Kerja Dalam Bahasa Inggris Bagi Siswa SMK Menggunakan Metode Demonstrasi. JAMU: Jurnal Abdi Masyarakat UMUS, 1(1). http://jurnal.umus.ac.id/index.php/jamu/article/view/317.

Warman, J. S., Mardian, V., Suryani, L., Fista, F. R., \& Irwan, I. (2020). Program Pelatihan Penigkatan Kemampuan Bahasa Inggris Anak-Anak Panti Asuhan Melalui Pemberdayaan Mahasiswa. Dinamisia : Jurnal Pengabdian Kepada Masyarakat, 3(2), 280-285. https://doi.org/10.31849/dinamisia.v3i2.3304.

Wijirahayu, S., Priyatmoko, H., \& Hadianti, S. (2019). Critical, Logical \& Creative Thinking in a Reflective Classroom Practices. International Journal of English Teaching (IJET), 8(1). $\quad$ https://www.researchgate.net/profile/SucianaWijirahayu/publication/335557469_Critical_Logical_Creative_Thinking_in_A_Refle ctive_Classroom_Practices/links/5e265253299bf1031e27bbab/Critical-LogicalCreative-Thinking-in-A-Reflective-Classroom-Practices.pdf.

Wijirahayu, S., \& Septiani, R. (2017). Developing TPR Vocabulary Peer Assessment in Primary School Classroom Practices. In UICELL Conference Proceeding. http://journal.uhamka.ac.id/index.php/uicell/article/view/1205.

Wijoyo, H. (2020). Analisis Minat Belajar Mahasiswa STMIK Dharmapala Riau Dimasa Pandemi Coronavirus Disease (Covid-19). Jurnal Pendidikan: Riset Dan Konseptual, 4(3), 396-404. https://www.researchgate.net/profile/HadionWijoyo/publication/343361623_Analisis_Minat_Belajar_Mahasiswa_STMIK_Dharm apala_Riau_Dimasa_Pandemi_Coronavirus_Disease_Covid-

19/links/5f24f7b3299bf1340497832e/Analisis-Minat-Belajar-Mahasiswa-STMIKDharmapala-Ri. 